\title{
Stressors factors experienced by hospitalized elderly from the perspective of the Neuman Systems Model
}

\author{
Estressores vivenciados por idosos hospitalizados na perspectiva do Modelo de Sistemas de Neuman \\ Estresores experimentados por personas mayores hospitalizadas en la perspectiva del Modelo de \\ Sistemas de Neuman
}

Paloma Horbach da Rosa ${ }^{1}$ (iD)

Margrid Beuter ${ }^{2}$ (i]

Eliane Raquel Rieth Benetti ${ }^{2}$ (i)

Jamile Lais Bruinsma² (iD

Larissa Venturini ${ }^{2}$ (D)

Carolina Backes² (iD)

1. Universidade Franciscana.

Santa Maria, RS, Brasil.

2. Universidade Federal de Santa Maria.

Santa Maria, RS, Brasil.
Corresponding author:

Paloma Horbach da Rosa.

E-mail: palomahorbach93@hotmail.com

Submitted on $06 / 06 / 2018$.

Accepted on 09/27/2018.

DOI: 10.1590/2177-9465-EAN-2018-0148

\begin{abstract}
Objective: To describe the stressful factors experienced by hospitalized elderly from the perspective of the Neuman Systems Model (NSM). Method: A descriptive qualitative study performed with 12 elderly hospitalized in a medical clinic of a teaching hospital in Rio Grande do Sul. Data production occurred from March to June 2016, through narrative interviews, subsequently transcribed, organized and submitted to the thematic analysis of Minayo, based on the NSM. Results: The stressors factors were classified in: intrapersonal - related to the clinical and psychosociocultural conditions resulting from the disease; interpersonal resulting from the relationships between elderly and health professionals; and extrapersonal - resulting from the institutional infrastructure, standards and routines. Conclusion and implications for practice: It is important that nursing professionals assist the elderly in the hospitalization process, aiming at minimizing the stressors experienced at this time of frailty and often of dependence, in order to preserve their physical-emotional stability and well-being.
\end{abstract}

Keywords: Elderly; Psychological Stress; Hospitalization; Geriatric Nursing

\section{Resumo}

Objetivo: Descrever os estressores vivenciados por idosos hospitalizados na perspectiva do Modelo de Sistemas de Neuman (MSN). Método: Estudo qualitativo descritivo realizado com 12 idosos hospitalizados em clínica médica de um hospital de ensino do Rio Grande do Sul. A produção dos dados ocorreu de março a junho de 2016, por meio de entrevista narrativa, posteriormente transcrita, organizada e submetida à análise temática de Minayo, fundamentada no Modelo de Sistemas de Neuman. Resultados: Os estressores foram classificados em: estressores intrapessoais - relacionados às condições clínicas e psicossocioculturais decorrentes da doença; interpessoais - decorrentes das relações entre idosos e profissionais da saúde e; extrapessoais resultantes da infraestrutura, normas e rotinas institucionais. Conclusão e implicações para a prática: É importante que os profissionais de enfermagem auxiliem o idoso no processo de hospitalização, visando diminuir os estressores vivenciados nesse momento de fragilidade e, muitas vezes, de dependência, objetivando manter sua estabilidade físico-emocional e bem-estar.

Palavras-chave: Idoso; Estresse Psicológico; Hospitalização; Enfermagem Geriátrica.

\section{REsumen}

Objetivo: Describir los estresores experimentados por personas mayores hospitalizadas en la perspectiva del Modelo de Sistemas de Neuman (MSN). Método: Estudio cualitativo descriptivo involucrando 12 pacientes de una clínica médica de un hospital docente de Rio Grande do Sul. La producción de datos tuvo lugar desde marzo hasta junio de 2016, mediante entrevista narrativa, posteriormente transcrita, organizada y sometida al análisis temático de Minayo, basada en el MSN. Resultados: Emergieron las clasificaciones: intrapersonales - relacionados con las condiciones clínicas y psicossocioculturales resultantes de la enfermedad; interpersonales - resultantes de las relaciones entre personas mayores y profesionales de salud y; extrapersonales - resultantes de la infraestructura, estándares y rutinas institucionales. Conclusión e implicaciones para la práctica: Los profesionales de enfermería deben asistir a la persona mayor en el proceso de hospitalización, buscando reducir los estresores experimentados en este momento de fragilidad y frecuentemente de dependencia, pretendiendo mantener su estabilidad física y emocional y bienestar.

Palabras clave: Personas Mayores; Estrés Psicológico; Hospitalización; Enfermería Geriátrica. 


\section{INTRODUCTION}

Population aging occurs rapidly in developed and developing countries. Demographic data indicate that the elderly population in Brazil is considered one of the largest in the world, with an expected increase of 4\% per year between 2012 and 2022. Thus, an average annual increase of more than 1.0 million elderly people ${ }^{1}$ is recorded, as a result of lower fertility and mortality rates, increased life expectancy, improved services and the use of new health technologies.

Over the years, there is a physiological decline in the body's functions, which implies biopsychosocial changes that are associated with unfavorable conditions, culminating in the development of chronic non-communicable diseases, comorbidities and injuries, which are consistent with the need for care in all levels of health care. ${ }^{2}$ Although hospital admission is recommended, solely, when all the options for managing the diseases are over, it is an important resource and is part of the health care network for the elderly. ${ }^{3}$

In this context, when the health needs of the elderly determine their hospitalization, the characteristics related to senescence have to be observed for the planning of care. ${ }^{4}$ This observation is important because the elderly hospitalize more frequently, the time of bed occupancy tends to be prolonged, readmissions are high and recovery slower, which demands longer time for the multiprofessional team. ${ }^{5}$ In addition, the hospital is an environment permeated by stressors. In this way, hospitalization can become exhausting for the elderly, as it causes changes in habits and lifestyles, distancing of family members, pets and personal belongings.

In addition, bed restriction, often necessary, causes functional loss, thus reducing the ability to wander and, occasionally, increasing the incidence of falls, with risk of fractures, ${ }^{6}$ conditions that may be perceived as stressors by the elderly. In this context, it should be emphasized that the elderly person should be valued and respected as he/she is, regardless of the stage of life in which he/she is found. ${ }^{4}$

Thus, it is assumed that the elderly experience stressors during hospitalization and, given different definitions for the term, this study was based on the Neuman Systems Model (NSM). For the theorist, stressors are characterized by forces or stimuli, present in the intrinsic or extrinsic environment, that act on the individual (system), and cause tension, impeding the maintenance of their equilibrium. ${ }^{7}$ In NSM, each person is considered as an open system, composed of a center, surrounded by concentric circles, in which are inserted the basic conditions of survival; intrapersonal, extrapersonal and interpersonal stressors; the reaction to stressors and the reaction to total unity, interacting with the environment. ${ }^{7}$

As for the classification of stressors proposed by Neuman, the internal environment or intrapersonal factors are all the forces within the person, such as conditioned responses (knowledge, emotions, fear, frustration, anxiety, anguish, impatience) and organic responses. The external environment are all interactions that occur outside the body, with the physical environment and unknown people. In this space, we include interpersonal factors, which arise from the interaction between individuals, rules and expectations, and extrapersonal factors, resulting from sociopolitical, cultural, work and financial pressures. ${ }^{7}$

Sustained by NSM, it is considered that the hospitalized elderly person is continuously interacting with internal and external stimuli, and in permanent transformation in the environment, in search of a dynamic state of harmony and balance. Thus, it is inferred that during the hospitalization the elderly experience different situations that can be evaluated as stressors and, given the gap in the studies that investigate this problem, it is sought to answer the following question: Which are the stressors experienced by the elderly during hospitalization?

It is considered that studies with this approach can make explicit the stressors experienced by hospitalized elderly people, instigate reflections and subsidize nursing actions inherent to this process, which help in the rehabilitation of the elderly's health and make the hospitalization period less stressful. Thus, considering that care for the elderly involves physiological, psychological, socio-cultural, developmental and spiritual aspects, ${ }^{7}$ the identification of stressors can favor the planning of nursing outcomes and interventions.

Together, the use of a Theoretical Model of Nursing makes it possible to consolidate nursing as science and art, in order to produce knowledge that corresponds to the needs and specificities of the profession, the person, the environment and the community. Thus, the use of NSM confers uniqueness to this study, because it is a fundamental epistemological contribution to the construction of knowledge and professional practice.

Therefore, the present study aims to describe the stressors experienced by hospitalized elderly from the perspective of the Neuman Systems Model.

\section{METHOD}

This is a qualitative and descriptive study, performed in a Medical Clinic of a teaching hospital in Rio Grande do Sul. Among the 19 elderly patients hospitalized at the clinic during the data collection period, two refused to participate in the study, five presented a low score in the Mini Mental State Examination (MMSE), not reaching the cutoff point. Thus, 12 elderly participated in the study, who met the inclusion criteria of being hospitalized for more than five days and presenting a preserved cognitive capacity.

The participants were selected by convenience and those who met the inclusion criteria were invited to participate in the study. Initially, the Mini Mental State Examination (MMSE) was applied for selective cognitive evaluation. For the standardization of scores, we adopted: illiterates $=19$ points; three years of 
schooling $=23$ points; seven years of schooling $=24$ points; more than seven years of schooling $=28$ points. ${ }^{8}$ After the MMSE, the objectives of the research and the Free and Informed Consent Term were presented.

The collection was carried out in the period from March to June of 2016, through a form with sociodemographic and clinical data to characterize the elderly; Katzs Scale Scoreto evaluate Instrumental Activities of Daily Living Scale (I.A.D.L) and narrative interview, with the triggering question: How has your day-to-day been here in the hospital, since you've been hospitalized, what situations have you stressed about? The interviews were conducted by the researcher and recorded in audio, under the authorization of the interviewee. The number of participants was determined by the need for information and quality of the data produced, and with 12 elderly people the recidivism and complementarity of the information about the object of study was reached. ${ }^{9}$

After the collection and transcription, for organization and presentation of the data, the information was identified by the letter "E" (elderly), followed by a consecutive cardinal numbering $(E 1, E 2 \ldots)$. Subsequently, the thematic analysis ${ }^{10}$ was carried out, with definition of the categories, according to NSM. In the analysis, in order to find the sense nuclei that constitute a communication, in which the existence indicates something for the presented objective, the determined phases were followed: pre-analysis, exploration of the material and treatment of the obtained results and, the interpretation of these..$^{10}$

The study was approved by the Research Ethics Committee, on January $12^{\text {th }}$ of 2016 , under opinion No. $1,387,311$. The ethical precepts of voluntary and consensual participation of each subject, formalized by the Free and Informed Consent Term, were respected.

\section{RESULTS}

The sociodemographic and clinical characterization of the elderly showed that seven elderly were male and five were female. Regarding age, six elderly were included in the age range of 60 to 69 years, five of 70 to 79 and one older than 80 years. About the marital status, eight were married, two divorced, one single and one widower. As for the profession, nine were retired, two were drivers and one a farmer. With regard to schooling, seven did not finish elementary school, three completed it and two were not literate. With application of the Katzs Scale, six of the participants were dependent on the I.A.D.L, three were semi-dependent and three were independent.

It was found that the majority of hospitalizations occurred due to cardiovascular diseases, followed by digestive, respiratory, infectious and traumatic diseases. Hypertension was the most frequent previous chronic condition (8), followed by respiratory diseases (2) and heart disease (1); an elderly patient had no prior pathology. It is noteworthy that during the hospitalization period, precautionary measures were adopted for contact with four participants, who presented positive cultures for resistant microorganisms. As for the diagnosis, the following were identified: Acute Myocardial Infarction (2), Vascular Brain Accident (2), Inflammation of the Intervertebral or Interarticular Disc (1), Spinal Cord Injury (1), Unspecific Hypoglycemia (1), Unstable Angina (1), Subdural Abscess (1), Gastroenteritis (1), and Deep Vein Thrombosis (1)

Regarding the use of devices that assisted in the maintenance of vital functions and in the treatment, it was verified that eight of the participants needed peripheral venous puncture, two used Central Venous Catheter and a Central Peripheral Insertion Catheter; five used bladder catheter in a closed system; three had a chest drain, and one elderly man used a nasoenteric catheter. In this aspect, the technology used for the treatment established and the level of dependence is related. In addition, the use of these devices may represent a stressor for the elderly, since they are invasive procedures that require specific techniques for installation and maintenance and, in most cases, cause pain to the patient.

\section{Stressors experienced by hospitalized elderly people}

From the analysis of the data, three thematic nuclei were built based on the NSM, which composed the description and led to the discussion of the results.

\section{Intrapersonal Stressors}

Intrapersonal stressors are those that act within the individual. They are all interactions that occur with the elderly, such as their knowledge, emotions (fear, frustration, anxiety) and variations of the organic system. ${ }^{7}$ By characterizing themselves as inner forces influenced by age (development), physical capacity (biological) and past experiences (psychological), in this category were included the stressors related to the diseases and clinical conditions of the elderly, hemodynamic and psycho-sociocultural changes due to illness and hospitalization, and implications of comorbidities.

Clinical changes related to the disease, such as restrictions on physical mobility, need for bed rest, prolonged hospitalization and situations of clinical instability, were cited by the elderly as stressors.

[...] the difficult days were those days that I spent more sick than I was, I even got pneumonia here, I stayed longer just in bed [...] there were some moments that I thought I would live no longer, that I wouldn't walk anymore, bad moments when I was only crying [...] I felt weak [...] and today I'm here, 100 days in the hospital, it was very stressful for me, I did not even think I was going to return to life, because I was between death and life [...] (E3). 
There was also frustration and fear of the elderly with their prognosis, including the imminent fear of death. During hospitalization, there were several situations that aroused this feeling in the patients, especially when they presented worsening of the clinical picture.

\section{[...] the only anguish is a surgery like I did [...] they opened my heart, put a saphenous vein, how could I not be distressed? It is not a toe operation, it is a risky operation, I could stay at the table (die) [...] (E5).}

[...] the doctor here said that I almost died. And if he had not attended to me, I would have died there [...] I felt a little shocked, you know? He told me right in the face, and I was not expecting it (crying) (E10).

In addition to these situations, the removal of family and environmental ties, awakened feelings of longing, sadness, loneliness and isolation, perceived as stressors.

[...] I just want to go home, I missed my home, my granddaughter [...] We involve an entire family [...] it's difficult, now I stopped, but at the beginning, about 15 or 20 days ago, I cried every day longing for my little girl [...] (E2).

[...] I am sad for staying away from the family, because not all family members can be together [...] they live in another state and cannot come here to stay with me [...] (E4).

[...] I'm very attached to my house, it's just me and the mother (crying) [...] it's not easy [...] Only I know what I'm going through (crying), I'm really missing them [...] here the time is killing me, because I am very lonely [...] (E6).

Still, being hospitalized, restricted to an unknown environment, to a limited physical space, is a stressor for the elderly, who feel trapped, with no freedom to act.

[...] I feel trapped here, I really wanted to be at home [...] we feel better, in our own things [...] (17).

[...] Here I am trapped, I have to be lied, me, who is accustomed to living at home, I go out all the time, I live in the campaign, there it's always 'back and forth' and here I am trapped [...] (I12).

Pain was also mentioned by the elderly as a stressor, especially in relation to performing invasive procedures.

[...] I took one out today, but I had two drains in the chest and it bothered me, it still bothers me, when I turn around in bed, I feel pain, it's not an unbearable pain, but when I turn around it hurts and it was a thick drain, there it hurts [...] (E12).
Regarding the intrapersonal stressors, related to the clinical and psycho-sociocultural conditions of the disease, the most cited were factors associated with impaired physical mobility, perceived dependence on health professionals, situations of clinical instability and pain, restrictions imposed by treatment and hospital routines, fear of death, feeling of sadness, longing and solitude resulting from hospitalization.

\section{Interpersonal Stressors}

Interpersonal stressors are forces that act between two or more individuals, such as resources and relationships with family, friends and professionals. ${ }^{7}$ From the analysis of the narratives, included in this category are the factors arising from the relationships between the elderly and health professionals and the relationship during the execution of the procedures.

It was observed that the relationships in the hospital environment are sometimes indifferent, mechanical and automated, hindering the perception of the other and massifying the professional performance, which may favor depersonalization and endanger the dignity, as mentioned by the elderly.

[...] I felt like one of the last people when I went to have the surgery. He got there and could not do it [...] it was kind of sad, because they put us aside and the doctor said that there wasn't a surgery [...] (E3).

[...] these days that they let me down there, in X-Ray, I stayed there alone, waiting, waiting and I was tense, heart beating. [...] it was the saddest thing, especially us who are where we don't know and at night we get lost [...] (E9).

It is understood that hospitalized elderly have their singularities, which need to be respected and preserved. The study participants pointed out that with hospitalization, their privacy was compromised, being accentuated according to the severity of the disease and the degree of dependence on care. In the meantime, the need to use diapers and rely on the nursing staff for perineal hygiene was also perceived by the elderly as a stressor.

[...] but then come two, three ladies to cleanse me, which is an embarrassing thing, it is what I was most ashamed of, the dirty person in the bed [...] (E5).

[...] There is no privacy, in a collective room like this; many people cannot afford privacy. I do not see if there are a lot of people looking at me, I see very little [...] What I do not like is when they change or shower me and I listen to a man's voice [...] I do not like to be looked at, but I only know that there is someone when I listen to the voice, because I do not see it, and it stresses me a lot [...] (E11). 
The hospitalized elderly need specific attention and care, in order to guarantee the resolution of the problems presented, including the limitations of aging. Care must be taken so that the elderly person does not have his/her autonomy relegated to an imperceptible plan, due to the hierarchy of care and the fragility situations inherent in hospitalization.

[...] what makes me stressed is them doubting me, to think that I am lying when I am telling the truth. That they did not even think I was lying that the tracheostomy (cannula) had come out, they (health professionals) thought I had taken it out on purpose, they doubted me, [...] (E8).

In addition to these aspects, hospitalization often requires invasive procedures performed by health professionals, which affects autonomy and, consequently, triggers discomfort and insecurity, which were perceived and mentioned as stressors.

[...] what makes us nervous is when they put these PICC (Peripherally Inserted Central Catheter) and central catheter [...] I had never done it in my life, so I felt nervous, I cried a lot, but I faced the reality and I did it [...] (E4).

[...] the moment I was a little nervous was when they pierced my neck to get a vein and a moment that made me more nervous was when they took out from my chest the drains (E5).

Among the interpersonal stressors resulting from the relationships between the elderly and health professionals, they included depersonalization, invasion of privacy and intimacy, disrespect for autonomy, and the performing of procedures that provoked fear and anxiety. Faced with these stressors, it is important for professionals to review their concepts about the elderly and the ethical issues that permeate care, overcoming approaches anchored in clinical-curative issues, in order to understand the totality, expressions and needs of the human being.

\section{Extrapersonal stressors}

Extrapersonal stressors are all interactions that occur outside the body, that is, it is the entire environment in which the elderly are exposed. ${ }^{7}$ In this category, there are presented the stressors arising from hospital infrastructure, norms and institutional routines, cited as stressors because they interfere in maintaining the well-being of the elderly.

[...] only the air conditioner is missing [...] because in the summer it's hot in here, it's very hot. [...] (E1).

[...] there was the situation of my bed, which was damaged, the head part wouldn't go up, and I always asking to change, but they did not fixed it. Then, when it was time for me to begin to sit down in bed, I began to insist [...] (E3).

The narratives of the elderly point out the inadequacy of the hospital structure to assist the elderly, which implies security and induces aggravators, stressors of the environment in which care takes place.

[...] I felt sad on the day I was in the ER (Emergency Room) [...] over there it is a bit complicated for an elderly person like me, to stay on those stretchers. There are a lot of people in there, but those in need of service are prone to staying there. [...] (E4).

[...] there is a lot that makes people feel stressed, especially when you come and stay down there (Emergency Room). I spent days on that narrow stretcher. I was very stressed, I had to go downstairs on a step ladder and I have a pain in my leg, so it was difficult for me to go up and down [...] (E11).

It is known that precautionary measures are often necessary and are elaborated according to the transmission mechanism of the pathologies. For elderly people who were in this situation, the requirement of the use of aprons and gloves was a stressful situation.

Someone wanted to see me and had to put on the uniform, because it is in isolation. Then I was very stressed, with shame (E3).

Still, it is understood that the elderly have particularities and requirements that need to be attended with skill, respect and empathy beyond the standardization of care. The narratives point out that sleep of the elderly should be the object of attention, since it is already compromised due to physiological changes characteristic of age and diseases, such as musculoskeletal and dementia.

[...] stressed in few moments, when we are sleeping and they come to give the medicine, come at the time of the bath and you have to take a shower, the time to take the medicine has to be of taking the medicine, we keep getting distressed [...] (E3)

[...] there is that thing, I'm just sleeping, getting to sleep, then I have to take the medication [...] that bothers the sleep (E8).

Regarding extrapersonal stressors, we observed situations related to infrastructure, norms and hospital routines, which 
influence the maintenance of the elderly's well-being. These issues, also presented as stressors, must be identified by professionals, trying to adapt them without harming the elderly's well-being.

\section{DISCUSSION}

Concomitant to aging there is an increase in chronic diseases and their complications, situations that intensify the number of hospitalizations of the elderly, as well as the length of stay. Hospitalization may lead to decreased functional capacity, physical weakness and emotional instability, as the hospital is permeated by stressors that interfere with well-being. In addition, patients are exposed to the risks of the hospital environment, which are accentuated for the elderly due to the immunosenescence process, towards the diseases and to the physiology of aging. ${ }^{11}$

The results of the present study indicate that the elderly person perceives the succession of capacity losses that have occurred, such as motor function and worsening of their clinical condition. This confrontation, with its current clinical and psychosocial conditions, amplifies the feeling of loss and weakens their internal coping resources, built throughout life. Since each person's Normal Line of Defense (NLD) varies according to age and development, ${ }^{7}$ it is inferred that the decrease in physiological reserves and chronic diseases due to aging can make the elderly more susceptible to stress, which makes the identification of the stressors and the preventive actions, priority.

Hospitalization, in different life cycles, is a situation experienced with anguish, but for the elderly it becomes a painful situation, due to the connection of the relationship of dependence to death. ${ }^{12}$ In addition, hospitalization favors the development of negative thoughts in the elderly, especially because of the fragility, tension, varied fears and loneliness, due to the prolonged stay in the hospital environment. This result corroborates a study carried out with 700 hospitalized patients, which showed that losing part of the body, fear of becoming dependent and result of the unknown treatment are experienced stressors during hospitalization. ${ }^{13}$

The removal of the family and environmental bonds, produced feelings of longing, sadness, loneliness and isolation. This is because the human being establishes material and psychological relationships with the environment where he/she lives, which transform physical space into meaningful space and representation for the individual, where all his/her experiences are developed. It is also in physical space that individuals interact and build their subjectivity. ${ }^{14}$ The environment has an emotional impact on the individual and when he/she has to leave it, for some reason, this can affect many aspects of his/her life.
When the elderly are hospitalized, there is a departure from their personal history, which can lead to suffering, feelings of abandonment and fear of the unknown. In this aspect, it is important that professionals understand that the family bond represents for the elderly a fundamental component for their well-being, in which they find support and intimacy for the various situations they face and relationships that ensure a space of belonging. The change in habits and behaviors induced by hospitalization cause changes in the NLD and require adaptation ${ }^{7}$ of the elderly, thus a welcoming attitude of nursing contributes significantly to minimizing the stressors of hospitalization.

It is known that the elderly present particularities, including related to adaptation in different spaces, different from the other age groups. Therefore, it is added that their health assessment should be done in a multidimensional way, in order to identify problems underlying the main complaint, including functionality, cognition, emotions, social and environmental issues, which interfere in the well-being, in the autonomy. ${ }^{15}$ Consequently, the performance of health professionals, especially nurses, is essential for the recovery process of the elderly, since it allows the identification of problems and stressors, and enables care to be systematized and qualified.

Pain was cited by the elderly as a stressor, especially during invasive procedures. In the meantime, it is pointed out that the relief of pain is a right of all people, and also of the elderly. To do this, it is necessary for health professionals to be prepared to assess pain throughout their life cycle and to intervene using the diversity of approaches available to act in an interdisciplinary way. ${ }^{16}$

However, results show that the daily routine of hospital care relationships favors depersonalization of the elderly and put in danger their dignity, because their singularities are not preserved and respected. Given this, care for the elderly should be guided by the maintenance of autonomy, in view of integral care, which respects ethical principles and strengthens the quality of care. ${ }^{17}$ The elderly need to be welcomed and have their anxieties, anguishes and fears identified in order to make this period less wearing.

Generally, healthcare teams that assist the elderly in hospitals are not specialized, so some particularities of this age group are not considered. Convergent with this statement, studies show that professionals often deal more with the disease that led to the hospitalization of the elderly, than with the physiological and psychological issues that disrupt it, failing to assist in a holistic way. ${ }^{4,14}$ These findings corroborate the different difficulties and challenges faced by the nursing team in the care and assistance of the hospitalized elderly, as well as the need for a care directed to the specificities of the elderly and their aging process as a whole. ${ }^{4}$ 
In this context, it is emphasized that respect for privacy is one of the needs and a right of the human being, to preserve his/her body from exposure and manipulation by others. ${ }^{18}$ In the hospital environment, lack of privacy is characterized by changes in physical space without the permission of the elderly and the exposure of the body and private parts during procedures. These situations can be mitigated by adapting the physical structure, using screens, curtains and covering parts of the body that do not need to be exposed during a procedure.

Regarding the need to wear diapers, it is pointed out that the loss of dependence is related to the insertion of diapers throughout the hospitalization, as the autonomy becomes progressively diminished during this period. ${ }^{19}$ In addition, the use of this care technology impairs issues related to self-image, self-perception and judgment of others. Faced with this stressor, it is important to establish dialogic relationships that provide security and comfort, because what seems to be a simple action for professionals can represent an invasion of privacy for the elderly. In this aspect, it is necessary to modify the concept of nursing actions as the elderly observe, think and feel the different forms of care. ${ }^{20}$

In addition to these aspects, the execution of invasive procedures triggers discomfort and insecurity. The unknown can cause negative reactions, such as changes in self-esteem and body image, psychological changes due to fear of death and anxiety. Regarding the attention to the elderly, it is pointed out that care has to be understood and implemented in its amplitude, bringing to the expertise of science the delicacy of treatment in relationships and the sensitivity to identify individual demands, values and expectations. ${ }^{21}$

The caregiver needs to see the elderly in a holistic way and value the demands, identified in the physiological, psychological, socio-cultural, developmental and spiritual dimensions, ${ }^{7}$ in an equitable way. However, in the current context of hospital institutions, mostly focused on the biomedical model, the art of caring is sometimes neglected. To intervene at this juncture and its stressful situations, it is necessary to go beyond the technicality and practice focused on the disease, considering the integrality of the elderly, in order to implement nursing interventions that meet beyond the physiological demands.

However, in order to carry out the assistance practice, it is necessary, among other conditions, to guarantee adequate infrastructure, with the availability of equipment, trained human resources and sufficient supplies of materials for the assistance rendered. In addition, the performance of professionals depends on these technologies, so that their lack can compromise the results. The issues raised by the elderly regarding inadequate infrastructure make it impossible to implement an important principle of the Unified Health System, which is completeness, and the obtaining of good results and interferes with the continuity of health care.
A study evidenced several weaknesses in the care of the elderly in an emergency unit, among them, an inadequate hospital environment for the elderly, which in turn impairs nursing care and delimits the autonomy and independence of the elderly within their potential. ${ }^{22}$ In addition, inadequate physical structure compromises patient safety as advocated by the National Program for Patient Safety. ${ }^{23}$

Generally, the accommodations provided to the elderly are inappropriate, considered the loss of muscle tone caused by the aging process. Improvisation has been constant in the health services, which compromises the humanized, welcoming and resolute assistance, ${ }^{24}$ and may also make it difficult to protect the privacy of the elderly, whose responsibility belongs to the health team. ${ }^{25}$ This reflects that services are not yet prepared to act through the particularities of the elderly, and difficulties are visible in the management and operation of innovative and effective strategies that contemplate the priorities of this population. ${ }^{26}$

When hospitalized, the elderly tend to lose their references, since they are inserted in a modified physical environment and thus experience other problems. ${ }^{27}$ Their concerns increase because they need to adapt to the limitations imposed by the disease and also to institutional routines. In this context, in addition to the organic changes related to hospitalization, physical facilities and coping with norms and routines, it is recommended to observe the emotional changes and to value the interpersonal relationships in the contact with the elderly. Given this result, considering that nurses occupy a strategic position and play an essential role in care, it is necessary for the nurse to evaluate the elderly's understanding of the guidelines and care received. ${ }^{28}$ This is because the knowledge of the elderly about interventions can minimize the stressor. ${ }^{7}$

The results of this study indicate that the sleeping of the elderly should be the object of attention. In this regard, it is inferred that it is important that the nurse is aware of the sleeping characteristics of the elderly, in order to prepare for possible damages due to their poor quality in relation to hospitalization. In the hospital, efforts should be made, as well as nonpharmacological resources, to improve sleep quality by avoiding the use of sedative drugs as much as possible due to the risks of their ingestion by the elderly. ${ }^{29}$ Alternatives to benefit from sleep can be instituted, such as the planning of nursing interventions during the day and adjustment of schedules of medications such as diuretics, considering the prolonged elimination of some medications due to the physiological changes inherent to aging.

Regarding extrapersonal stressors, one can see the low investments and financial resources of the hospital, which is also a characteristic of many of the country's public hospitals, and, as far as they are concerned, end up interfering in the therapeutic process. The elderly, for reasons related to chronic diseases and aging itself, internalize and repeat more often, and, in turn, stressing due to the lack of adequate infrastructure for their care. 


\section{CONCLUSION AND IMPLICATIONS FOR PRACTICE}

The study identified sociodemographic and clinical characteristics of the elderly as well as describing the intrapersonal, interpersonal and extrapersonal stressors experienced by them during hospitalization. Knowing the stressors experienced by elderly hospitalized in medical clinic allows to reflect on the need of nursing care, in order to promote a holistic and integral interaction.

It was verified that the elderly experienced different stressors during hospitalization, which require early identification to be attenuated as soon as possible, aiming to promote the maintenance of the elderly's well-being. Thus, knowing the stressors and classifying them in intrapersonal, interpersonal and extrapersonal, as recommended by NSM, provides subsidies for the nursing team to qualify the assistance and to meet the needs of the aging human being. Therefore, the nurse, as a professional who assists and educates, can help the elderly to deal with stressors and to mobilize their coping strategies, which will help to maintain homeostasis.

In addition, it is pointed out that the use of a nursing theory for the recognition of these stressors provides the nurse with subsidies for critical thinking, clinical judgment and decisionmaking, which support the planning of nursing outcomes and interventions. Therefore, it is important to carry out studies to investigate the stressors and to indicate possibilities of interventions to minimize them, in order to qualify nursing care for hospitalized elderly people, based on theoretical support.

\section{REFERENCES}

1. Ministério do Planejamento, Orçamento e Gestão (BR). Instituto Brasileiro de Geografia e Estatística (IBGE). Mudança Demográfica no Brasil no Início do Século XXI: Subsídios para as projeções da população. Rio de Janeiro: IBGE; 2015.

2. Veras R. A urgente e imperiosa modificação no cuidado à saúde da pessoa idosa. Rev Bras Geriatr Gerontol [Internet]. 2015 Jan/Mar; [cited 2016 Dec 12]; 18(1):5-6. Available from: http://www.scielo.br/scielo. php?script=sci_arttext\&pid=S1809-98232015000100005. DOI: http:// dx.doi.org/10.1590/1809-9823.2015.0059

3. Nunes BP, Soares MU, Wachs LS, Volz PM, Saes MO, Duro SMS, et al. Hospitalization in older adults: association with multimorbidity, primary health care and private health plan. Rev Saúde Pública [Internet]. 2017 May; [cited 2018 Jan 23]; 51(43):1-9. Available from: http://www.scielo. br/scielo.php?pid=S0034-89102017000100234\&script=sci_abstract. DOI: http://dx.doi.org/10.1590/s1518-8787.2017051006646

4. Sanguino GZ, Previato GF, Silva AF, Meireles VC, Góes HLF, Baldissera VDA. The nursing work in care of hospitalized elderly: limits and particularities. J Res Fundam Care [Internet]. 2018 Jan/Mar; [cited 2018 Apr 30]; 10(1):160-6. Available from: http://bases.bireme.br/cgi$\mathrm{bin} / \mathrm{wxislind}$.exe/iah/online/?IsisScript=iah/iah.xis\&src=google\&base= BDENF\&lang=p\&nextAction=Ink\&exprSearch=32260\&indexSearch= ID. DOI: 10.9789/2175-5361.2018.v10i1.160-166

5. Santos TD, Santos FHE, Cunha KCS, Chibante CLP. Segurança do paciente idoso hospitalizado: uma revisão integrativa. Cogitare Enferm [Internet]. 2016 Jul/Sep [cited 2017 Nov 10];21(3):1-10. Available from: https://revistas.ufpr.br/cogitare/article/view/44223. DOI: http://dx.doi. org/10.5380/ce.v21i3.44223
6. Alexandre TS, Corona LP, Nunes DP, Santos JLF, Duarte YAO, Lebrão ML. Disability in instrumental activities of daily living among older adults: gender differences. Rev Saúde Pública [Internet]. 2014 Jun; [cited 2016 Dec 12]; 48(3):378-89. Available from: http://www.scielo.br/scielo. php?pid=S0034-89102014000300379\&script=sci_abstract\&tlng=pt. DOI: http://dx.doi.org/10.1590/S0034-8910.2014048004754

7. Neuman B. The Neuman systems model. In: Neuman B, Fawcett J, editores. The Neuman systems model. 5a ed. Upper Saddle River (NJ): Pearson; 2011.

8. Moraes EN. Atenção à saúde do Idoso: Aspectos Conceituais. Brasília (DF): Organização Pan-Americana da Saúde; 2012.

9. Minayo MCS. Amostragem e saturação em pesquisa qualitativa: consensos e controvérsias. Rev Pesq Qualit [Internet]. 2017 Apr; [cited 2018 Jun 25]; 5(7):1-12. Available from: https://editora.sepq.org.br/ index.php/rpq/article/view/82/59

10. Minayo MCS. O Desafio do Conhecimento: pesquisa qualitativa em saúde. 14 ${ }^{a}$ ed. São Paulo (SP): Hucitec; 2014.

11. Izaias EM, Dellaroza MSG, Rossaneis MA, Bele RA. Custo e caracterização de infecção hospitalar em idosos. Ciênc Saúde Coletiva [Internet]. 2014 Aug; [cited 2016 Dec 12]; 19(8):3395-402. Available from: https://www.scielosp.org/scielo.php?pid=S1413 81232014000803395\&script=sci_arttext\&tlng=pt. DOI: https://doi. org/10.1590/1413-81232014198.12732013

12. Santos G, Sousa L. Qualidade de vida em pessoas idosas hospitalizadas: comparação da admissão com a alta do internamento. Rev Kairós Gerontol [Internet]. 2013 Mar; [cited 2016 Dec 12]; 16(2):7-25. Available from: https://revistas.pucsp.br/index.php/kairos/article/viewFile/17625/13126

13. Chhari N, Mehta SC. Stress among patients during hospitalization: A study from Central India. Natl J Community Med [Internet]. 2016; [cited 2017 Nov 10]; 7(4):274-7. Available from: http://www.scopemed. org/?mno=230741

14. Soares NN, Custódio MRM. Impactos emocionais da alteração da rotina em idosos hospitalizados. Enc Rev Psicol [Internet]. 2011; [cited 2016 Dec 12]; 14(21):9-23. Available from: http://pgsskroton.com.br/ seer/index.php/renc/article/view/2491

15. Lira LN, Santos SSC, Vidal DAS, Gautério DP, Tomaschewski-Barlem JG, Piexak DR. Diagnósticos e prescrições de enfermagem para idosos em situação hospitalar. Av Enferm [Internet]. 2015 May/Aug; [cited 2017 Nov 10]; 33(2):251-60. Available from: http://www.scielo.org.co/scielo. php?script=sci_arttext\&pid=S0121-45002015000200007. DOI: http:// dx.doi.org/10.15446/av.enferm.v33n2.30762

16. Pereira LV, Vasconcelos PP, Souza LAF, Pereira GA, Nakatani AYK, Bachioni MM. Prevalência, intensidade de dor crônica e autopercepção de saúde entre idosos: estudo de base populacional. Rev Lat Am Enferm [Internet]. 2014 Jul/Aug; [cited 2017 Nov 10]; 22(4):662-9. Available from: http://www.scielo.br/scielo.php?script=sci_arttext\&pid=S0104$11692014000400662 \&$ Ing=en\&nrm=iso\&tlng=pt. DOI: http://dx.doi. org/10.1590/0104-1169.3591.2465

17. Couto FBDE. Cuidado do idoso no hospital e em internação domiciliar: o que há de diferente? Rev Kairós Gerontol [Internet]. 2015 Jun; [cited 2018 Jan 23]; 18(no.esp.19):57-76. Available from: https://revistas. pucsp.br/index.php/kairos/article/view/26598

18. Lima OBA, Lopes MEL, Oliveira AMM, Carvalho GDA, Melo VC. Conduct of nurses in care of hospitalized elderly. J Nurs UFPE On Line [Internet]. 2014 Apr; [cited 2018 Jan 23]; 8(4):814-9. Available from: https:// periodicos.ufpe.br/revistas/revistaenfermagem/article/view/9747

19. Bitencourt GR, Alves LAF, Santana RF. Practice of use of diapers in hospitalized adults and elderly: cross-sectional study. Rev Bras Enferm [Internet]. 2018 Mar/Apr; [cited 2018 May 1]; 71(2):3439. Available from: http://www.scielo.br/scielo.php?pid=S003471672018000200343\&script=sci_abstract\&tlng=es. DOI: http://dx.doi. org/10.1590/0034-7167-2016-0341

20. Alves LAF, Santana RF, Schulz RS. Percepções de idosos sobre a utilização de fraldas durante a hospitalização. Rev Enferm UERJ [Internet]. 2014 May/Jun; [cited 2018 Jan 23]; 22(3):371-5. Available from: http://www.e-publicacoes.uerj.br/index.php/enfermagemuerj/ article/view/13727 
21. Lobo LF, Puggina AC, Trovo MM. Estratégias de Humanização para o atendimento ao idoso hospitalizado: uma revisão integrativa. Rev Enferm Atual [Internet]. 2014; 70(8):12-8.

22. Nascimento ERP, Silva SG, Souza BC, Souza DD, Netto AG. Environment of a hospital emergency unit for the elderly care: perception of nursing professionals. Rev Esc Anna Nery [Internet]. 2015 Apr/Jun; [cited 2018 Jan 23]; 19(2):338-42. Available from: http://www.scielo.br/scielo. php?script=sci arttext\&pid=S1414-81452015000200338\&lng=en\&nrm =iso\&tlng=en. DOI: http://dx.doi.org/10.5935/1414-8145.20150046

23. Ministério da Saúde (BR). Programa Nacional de Segurança do Paciente (PNSP). Portaria № 529, de 1ํ de abril de 2013. Institui o Programa Nacional de Segurança do Paciente (PNSP). Brasília (DF): Ministério da Saúde; 2013 [Internet]. [cited 2018 Feb 20]. Available from: http://www. saude.mt.gov.br/upload/controle-infeccoes/pasta2/portaria-msgm-n529-de-01-04-2013.pdf

24. Souza AS, Andrade CC, Reis Junior AP, Meira EC, Menezes MR, Gonçalves LHT. Atendimento ao idoso hospitalizado: percepções de profissionais de saúde. Ciênc Cuid Saúde [Internet]. 2013 Apr/Jun; [cited 2018 Jan 23]; 12(2):274-81. Available from: http://www.revenf.bvs.br/ scielo.php?script=sci_arttext\&pid=S1677-38612013000200010. DOI: 10.4025/cienccuidsaude.v12i2.18999

25. Pupulim JSL, Sawada NO. Percepção de pacientes sobre a privacidade no hospital. Rev Bras Enferm [Internet]. 2012 Jul/Aug; [cited 2018 Jan 23]; 65(4):621-9. Available from: http://www.scielo.br/scielo.
php?script=sci_arttext\&pid=S0034-71672012000400011. DOI: http:// dx.doi.org/10.1590/S0034-71672012000400011

26. Medeiros SG, Morais FRR. Organização dos serviços na atenção à saúde da idosa: percepção de usuárias. Interface (Botucatu) [Internet] 2015; [cited $2018 \mathrm{Jul} 25]$; 19(52):109-19. Available from: http://www. scielo.br/pdf/icse/v19n52/1807-5762-icse-19-52-0109.pdf

27. Both JE, Leite MT, Hildebrandt LM, Beuter M, Muller LA, Linck CL. Qualification of the nursing team by means of convergent-care research: contributions to the care of the hospitalized elderly person. Rev Esc Anna Nery [Internet]. 2014 Jul/Sep; [cited 2018 Jan 23]; 18(3):486-95. Available from: http://www.scielo.br/scielo.php?script=sci_arttext\&pid $=$ S1414-81452014000300486. DOI: http://dx.doi.org/10.5935/14148145.20140069

28. Lima Junior JRM, Sardinha AHL, Gonçalves LHT, Coutinho NPS Pasklan ANP, Santos MA. Cuidados de enfermagem e satisfação de idosos hospitalizados. Mundo Saúde [Internet]. 2015 Jan; [cited 2018 Jan 23]; 39(4):419-32. Available from: http://pesquisa.bvsalud.org/ bvsms/resource/pt/mis-37771

29. Monteiro NT, Ceolim MF. Qualidade do sono de idosos no domicílio e na hospitalização. Rev Texto Contexto Enferm [Internet]. 2014; [cited 2018 Jan 23]; 23(2):356-64. Available from: http://www.scielo.br/scielo. php?script=sci_arttext\&pid=S0104-07072014000200356\&lng=en\&tln g=en. DOI: http://dx.doi.org/10.1590/0104-07072014000190013 